\title{
Why health promises don't win federal elections
}

\author{
C Cite as: CMAJ 2019 November 11;191:E1257-8. doi: 10.1503/cmaj.1095832
}

Posted on cmajnews.com on Oct. 20, 2019

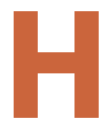

ealth advocates often appeal to federal parties to put health care on the agenda during election campaigns. This year, some parties answered the call, with bold pharmacare promises from the Liberals, New Democrats and Greens.

But it's rare that any policy issue makes or breaks an election, and health care is no exception, says Nelson Wiseman, a political science professor at the University of Toronto. "If you ask people if they are in favour of pharmacare, sure they'll say yes, and the parties might have differ- ent nuanced positions, but that isn't driving the vote."

Canadian elections are more often driven by the image of leaders and whom voters feel they can trust, he says. In some areas of Canada, this is ingrained and predictably partisan. "It doesn't matter who promises what about health care Alberta is going to vote Conservative," says Wiseman.

That may be why the needle didn't move much following Justin Trudeau's brownface scandal. As much as a leader may disappoint their base, in a tight race, "a lot of voting is just to keep the other guy out," says Wiseman. Even so, he notes, "I'm surprised we've heard as little as we have about pharmacare."

Health care is a tricky issue to address at the federal level because it's largely a provincial responsibility. Federal parties can't do much more than promise to cut bigger cheques to provinces, and regardless of the strings attached, provinces decide how the money is spent.

"Exceptions are largely in the regulatory field, or in the attempt to encourage collaborative activity across the provinces," says

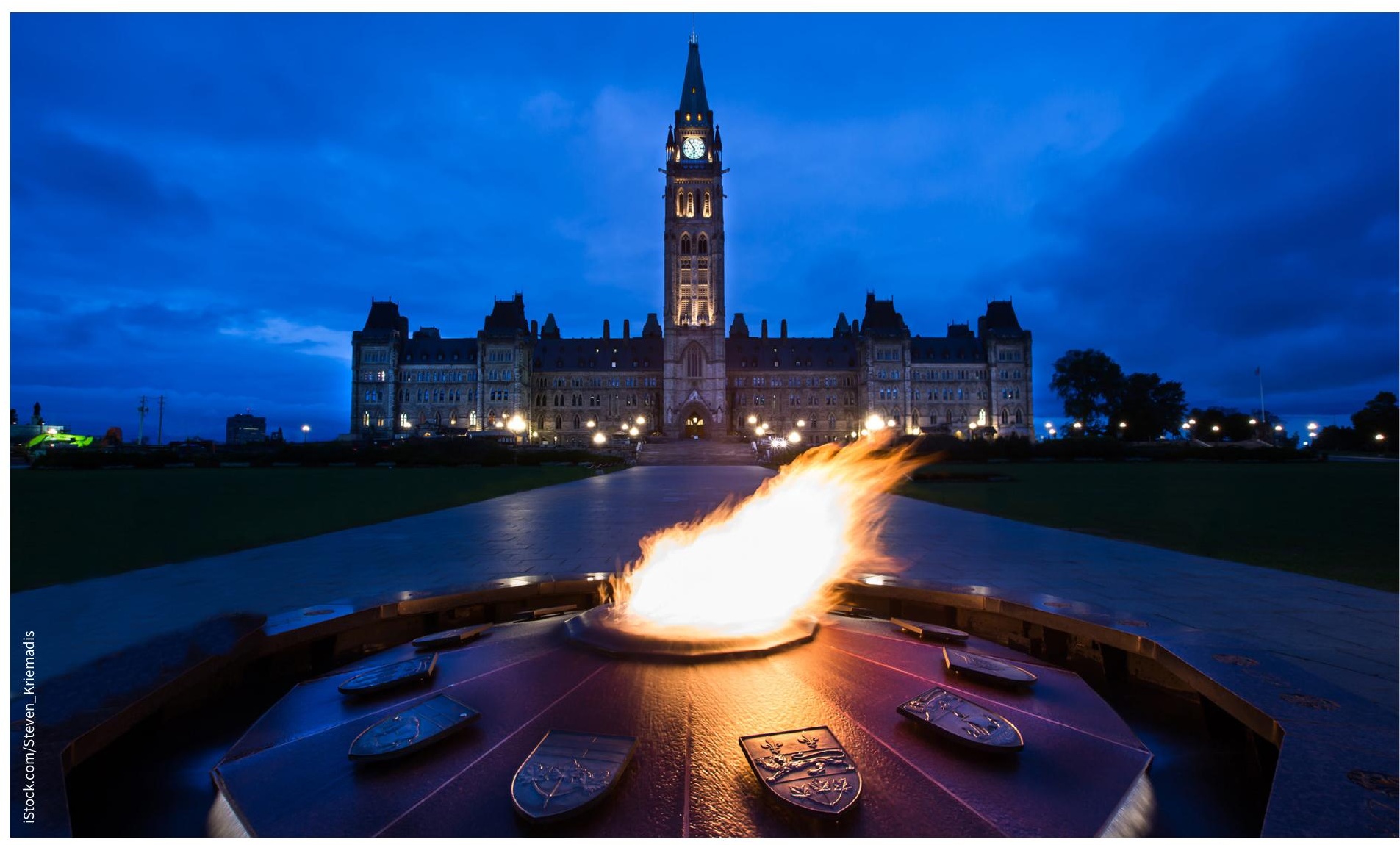

Canadians say they care about health care, but it seldom determines how they vote. 
Katherine Fierlbeck, a professor of political science at Dalhousie University. However, an electoral campaign is the worst time to discuss such highly technical issues. Unless an issue is reducible to a good soundbite, "it can get pushed under the table," says Fierlbeck.

There can also be tensions within parties about health care topics. "This is especially true for an incumbent government," she says. When Dr. Jane Philpott was minister of health, for example, there was tension over pharmacare between the "leftish wing" of the party and the "neoliberal wing," personified by Finance Minister Bill Morneau. "Morneau clearly and publicly espoused a limited pharmacare program," yet the Liberals ended up committing to universal coverage on the campaign trail. This may explain why their platform was short on detail.

"All major federal health policy is usually determined in the finance depart- ment," Fierlbeck says. "So while the neoliberal wing of the Liberal government is silent in this electoral campaign, they still have their hands on the reins."

Health care has the advantage, at least, of being an issue Canadians care about and one on which parties are less polarized in their stances. By comparison, "if you think about how hard people have worked for generations to get the environment on the table in the same way, I think that tells us something," says Keith Banting, professor emeritus in the department of political studies at Queen's University.

This election saw federal parties focus more than usual on policy, mainly because Canadians were underwhelmed with the leaders, according to Banting. "If anything, the leaders are weakening in public esteem over time, so what can parties do? Well, they throw a million policy initiatives at you because that's all they've got."
Canada's relatively stable economy freed public attention for other issues, he says. The Conservatives' centrist platform also shifted the dynamic of debate. Under Stephen Harper, the party was pitching another vision of Canada, suggests Banting, and elections during that era were "a little more ideological, more values based, so there's less need for detailed policy."

The fact that all major parties made health care commitments this time around "tells you that they think there is political leverage in addressing health care," he says. To affect the vote, however, "the parties have to be divided," says Banting. Policy may end up having been more important in this election, but in the case of health, "everyone is moving to the centre and moving to similar issues so it may not shift the vote as much."

Lauren Vogel, CMAJ 